The Council decided to participate in a scheme for a Joint Secretariat and Office Accommodation arranged by the Royal College of Surgeons.

The Council has appointed a representative to serve on a Committee of the Royal College of Physicians for the revision of "The Nomenclature of Diseases."

A sub-committee was appointed to draw up a report upon the Regionalisation of the Ophthalmic Services of London. This report has been modified by the Council and will be forwarded to the Association of the Ophthalmic Hospitals of London.

A sub-committee has been appointed to draw up a report upon the Ophthalmological aspects of the White Paper, which report after approval will be submitted to the Joint Committee of the three Royal Colleges.

The expenses of the Council have, as in the past, been met by contributions from its members.

\title{
OPHTHALMOLOGICAL SOCIETY OF THE UNITED KINGDOM
}

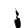

THE Annual Congress of the Ophthalmological Society of the United Kingdom was held at the Royal Society of Medicine on Friday and Saturday, March 31 and April 1, 1944. Considering the difficult circumstanes there was a very good attendance, especially of visitors, the latter consisting mainly of ophthalmic surgeons of the American Armed Forces. The President, Dr. H. M. Traquair, M.D.; F.R.S.Ed., opened the proceedings with a short address of welcome to members and visitors, and followed this by the Presidential address upon "The Nerve Fibre Bundle Defect," an illuminating discourse upon an aspect of the subject of which the President is an acknowledged master. The discussion which followed was upon "ocular psychoneuroses"' (excluding Miners' nystagmus), opened by Mr. R. C. Davenport and Squadron Leader J. H. Doggart on general lines. The subject was developed along special lines-by many members and visitors, the former including Professor Riddell, Mr. O. Gayer Morgan, Major Stenhouse Stewart, and Squadron Leader A. G. Palin, and the latter, Air Commodore R. D. Gillespie, and Dr. D. W. Winnicott, who enlarged upon the children's aspect.

The first part of the afternoon was devoted to a joint clinical meeting with the Ophthalmological Section of the Royal Society of Medicine. A large number of very interesting cases of all kinds were examined, and subsequently described and discussed. After the discussion Dr. Andrew Paterson read a paper upon "concentric restriction of vision from unilateral cerebral lesion," which was well 
illustrated by perimetric observations. Dr. Kate Hermann then gave her paper on "sphenoidal mucocele as a cause of the ophthalmoplegic migraine syndrome," which was particularly interesting. The rapid recovery described after operative interference was remarkable. The session closed with a paper by Captain G. Blum, Miss J. M. Dollar, and Professor Sorsby on the subject " the use of plastic material for scleral wounds," in which the result of trials of various plastics for sealing scleral wounds in experimental animals was described. The paper was in the nature of a preliminary communication; specimens of the plastics used were exhibited.

On the second day the session opened with a Discussion upon "virus affections of the eye." This was opened by a visitor, Dr. C. H. Andrewes, who described the nature of viruses in general, and. gave an interesting account of the latest work upon the subject, and by Professor Sorsby who specialised upon the ophthalmological aspect. The subject was well discussed; the speakers included Colonel R. E. Wright, Mr. A. F. MacCallan, who spoke on trachoma, Mr. H. Neame, who gave an account of herpes, particularly in its relation to chicken-pox, and Dr. A. Loewenstein.

The' Discussion was followed by the Annual General Meeting of the Society. The Honorary Secretary, Mr. F. W. Law, read the minutes of the last Meeting, which were approved; the Annual Report of the Society was received and also approved. The Honorary Treasurer, Sir Arnold Lawson, made a statement on the Balance Sheet, and officers for $1944-45$ were elected. A vote of thanks to the President and officers was carried with acclamation; to which the President briefly replied. The meeting was followed by the presentation of the Report of the Council of British Ophthalmologists, which was discussed and finally accepted., A copy of the Report appears elsewhere in this issue.

The Saturday afternoon was devoted to papers, of which there were five. Mr. E. Wolff gave a most interesting account of "hyaline bodies in the intra-ocular fluids and tissues," and Mr. M. L. Hine reported "a sequel to the case of spontaneous cure of retinal glioma;" in which he described the occurrence of this neoplasm in the third generation. Major King and Major Samuel gave a paper upon "fractures of the orbit," well illustrated by X-ray photographs, in which the methods of treatment of the condition were outlined. Major J. Minton gave a general account of "ophthalmic experiences in the East," and Major Philps described the use of "radon seeds in the treatment of retinoblastoma."

It was a valuable and enjoyable Congress, and many of the papers gave rise to interested discussion and comment. All the proceedings together with a report of the Joint Clinical Meeting will appear in the Transactions of the Ophthalmological Society of the United Kingdom for 1944. 